\title{
River Relationships: For the Love of River
}

\author{
Sandra Wooltorton ${ }^{1}$, Anne Poelina ${ }^{1}$, and Len Collard ${ }^{2}$ \\ ${ }^{1}$ The University of Notre Dame Australia - Broome Campus \\ ${ }^{2}$ The University of Western Australia - Claremont Campus
}

August 4, 2021

\begin{abstract}
In our writing, we voice stories of two Australian rivers to convey Indigenous ways of knowing and being. Interweaving academic literature, nature writing and creativity, we craft a story of reconnection that is transformative, action-oriented and potentially political. An open mind, place-intuition and the process of attending can deepen our river relationships, creating a sense of love and communicative connectedness. Paying deep attention, we notice meanings embedded in plain sight, within hearing range of rivers and watery places. Our relationships may be 'in our faces' such as the wind, or the air, water or bushes nearby. We communicate across binaries to experience the dissolution of imagined barriers. Feeling, hearing, writing and storytelling can support verbalising of experience, helping to bring to mind place-wisdom. It offers an everyday possibility for people now estranged from their riverine kin. The process uses a post human-centred, common worlds frame to consider the Anthropocene in regenerative ways. It is creative and liberating, and rivers are dying for people to take action by speaking out for and with our greater selves. In this learning journey, we synthesise learnings, hoping to inspire people everywhere to hear the call of rivers, to respond, take action and learn to love their rivers again.
\end{abstract}

\section{Hosted file}

Final River Relations Resubmission, with authors.docx available at https://authorea.com/ users/426634/articles/532832-river-relationships-for-the-love-of-river 